Mr Milorad Vidović, dipl. inž.

Mr Slobodan Cvetić. dipl. inž.

Saobraćajni fakultet, Beograd
OPTIMIZACIJA KORIŠČENJA POSTOJEĆIH KOMPLEKSA ZA SKLADIŠTENJE UBOJNIH SREDSTAVA

UDC: 623.485 .001 .573

Rezime:

Eksploatacija postojećih kompleksa za skladištenje ubojnih sredstava (UbS) povezana je sa problemima koji se, pre svega, odnose na postizanje zahtevane bezbednosti uskladištenog materijala i objekata u okruženju. Ovakva situacija posledica je promene propisa $u$ oblasti definisanja bezbednosnih rasiojanja, $i$ približavanja objekata okruženja skladištu. Međutim, $i$ u ovim uslovima postojeća skladišta mogu funkcionisati na zadovoljavajući način uz primenjivanje odgovarajućih optimizacionih postupaka koji će povezati zahteve za skladištenjem $i$ ograničenja koja nameće okruženje. Razvijen je jedinstveni model čijim korišćenjem je omogućeno definisanje maksimalne količine UbS koja se može smestiti u skladišni kompleks uz zadovoljavanje svih bezbeânosnih zahteva.

Ključne reči: ubojna sredstva, skladištenje, bezbednosna rastojanja, optimizacija, struktura objekata, optimizacioni modeli.

\title{
OPTIMIZATION OF APPLICATION OF EXISTING BUILDING COMPLEXES FOR EXPLOSIVE STORAGE
}

\section{Summary:}

Application of existing building complexes for explosive storage is connected with problems relating above all, to how to obtain the required safety of stored explosives as well as of surrounding buildings. Such a situation arises from the change in regulations defining safety distances and distances between a storage building complex and surrounding buildings. Nevertheless, even in these conditions the existing storage buildings can be used in a satisfactory way, appropriate optimization procedures which connect storage demands with constraints imposed by the surroundings being applied. The complex model developed here enables the definition of the explosive maximum quantity vhich can be stored in a storing complex while respecting all safety instructions.

Key words: explosives, storage, safety distances optimization, building complex structure, optimization models.

\section{Uvod}

Skladišni kompleksi namenjeni za čuvanje opasnih materija klase 1 predstavljaju veoma značajno, potencijalno mesto nastanka akcidentnih događaja. Posledice ovih događaja mogu biti katastrofalne, jer mogu ugro- ziti ljudske živote, $i$ izazvati velike materijalne gubitke. Pored toga, ne treba zanemariti ni negativan uticaj eventualnih akcidenata na borbenu sprem. nost i efikasnost OS.

Postojeći skladišni kompleksi, po pravilu, zauzimaju velike površine zemljišta a za njihovu izgradnju i obe- 
zbeđenje potrebne infrastrukture $u-$ lagana su znatna sredstva. Sa druge strane, zbog neophodne bezbednosti okruženja skladišnog kompleksa i uskladištenog materijala, njihovo funkcionisanje, u značajnoj meri, može biti ugroženo, pri čemu se, kao dominantni razlozi, mogu izdvojiti:

- promena strukture uskladištenog materijala koja se manifestuje kroz povećanje stepena opasnosti u procesima skladištenja,

- promena regulative $\mathbf{u}$ oblasti skladištenja, koja zahteva obezbeđenje većih bezbednosnih rastojanja,

- smanjenje rastojanja između objekata u okruženju i objekata u skladišnom kompleksu, kao posledica želje da se iskoristi inftrastruktura koja je nastala gradnjom skladišnog kompleksa.

U ovakvim uslovima, jedine mogućnosti za ostvarivanje tražene bezbednosti jesu osvajanje novih lokacija za skladišne komplekse i rekonstrukcija postojećih skladišnih kompleksa.

Osvajanje novih lokacija, po pravilu, jeste aktivnost koja nosi veliki broj problema, pre svega zbog potrebe za izdrajanjem značajnih investicionih sredstava.

Rekonstrukcija postojećih skladišta, u rećini slučajeva, predstavlja znatno bclju alternativu, ali zahteva precizne optimizacione postupke koji će obezbediti da se zadate količine materijala, uz zadovoljenje svih bezbednosnih zahteva, u skladišni kompleks smeste uz minimalna investiciona ulaganja. Cilj optimizacije postojećih skladišta može biti i zahtev za smeštanjem maksimalnih količina materijala na postojeću lokaciju uz ispunjenje svih bezbednosnih zahteva.

\section{Osnovni aspekti definisanja bezbednosnih rastojanja}

Pri smeštanju i čuvanju eksplozivnih materija u skladišnom objektu postoji opasnost da se nekim od ob- lika dejstava ovih opasnih materija ugroze ljudi ili objekti u okruženju. Zbog toga se, regulativom iz oblasti zaštite od delovanja opasnih materija, propisuju minimalna bezbednosna rastojanja koja se :moraju ostvariti, kako između skladišnih objekata i objekata u okruženju, tako i između skladišnih objekata međusobno.

Bezbednosna rastojanja između skladišnih objekata i objekata u okruženju imaju za cilj da zaštite potencijalno ugrožene ljude i objekte, tako što onemogućavaju da se oni nađu u zoni dejstva eksplozivnih materija. Veličina ovih rastojanja zavisi od karaktera materija i prirode objekta koji se štiti, tako da se posebna rastojanja definišu za javne, stambene, industrijske i druge objekte.

Bezbednosna rastojanja između skladišnih objekata uvode se, pre svega, radi onemogućavanja prenošenja dejstva eksplozije iz jednog objekta, u kome se desio incident, na drugi objekat. Ovom merom incident $u$ skladišnom kompleksu se lokalizuje na samo jedan objekat.

Veličina bezbednosnih rastojanja zavisi od oblika dejstva eksplozivnih materija. Analiza ovih dejstava ukazuje na to da se mogu pojaviti sledeće - vrste opasnosti:

- dejstvo vazdušnim udarnim talasom (klase 1.1 i 1.5),

$$
\text { - toplotno dejstvo (klasa } 1.3 \text { ), }
$$
nata (klasa 1.2).

Sva bezbednosna rastojanja mogu se svrstati u dve osnovne grupe:

- koja zavise isključivo od oblika dejstva eksplozivnih materija i karakteristika skladišnih objekata,

- koja zavise od oblika dejstva eksplozivnih materija, uskladištene količine i karakteristika skladišnog objekta.

Ova bezbednosna rastojanja predstavljaju se relacijama:

$$
a_{c}=f(o, s)
$$




$$
a_{q}=f(q, o, s)
$$

gde je:

$a_{c}$ - bezbednosno rastojanje koje ne zavisi od uskladištene količine eksplozivnih materija,

$a_{q}$ - bezbednosno rastojanje koje zavisi od uskladištene količine eksplozivnih materija,

$\mathrm{q}$ - količina eksplozivnih materija $u$ skladišnom objektu,

o - vrsta, odnosno oblik dejstva eksplozivnih materija,

s - karakteristike skladišnog objekta.

Bezbednosna rastojanja posledica su regulativnih mera koje postaju sve oštrije i univerzalnije. Na njihovo primenjivanje, pored redovnih instrumenata predviđenih regulativnim merama, obavezuje sve više i porast nivoa svesti ljudi. One dobijaju međunarodni karakter, što može, u slučaju njihovog neprimenjivanja, dovesti do pọtpune međunarodne blokade pri realizaciji robnih tokova sa eksplozivnim materijama.

\section{Koncept optimizacije funkcionisanja postojećih skladišnih kompleksa}

Jedan od veoma značajnih problema, na koji se nailazi pri eksploataciji postojećih skladišta eksplozivnih materija, odnosi se na nemogućnost njegovog optimalnog korišćenja, sa aspekta iskorišćenja raspoložive površine, zbog nedovoljnih rastojanja između skladišnih objekata. Ovaj problem je još izraženiji kada se zna da se nove lokacije za skladišta eksplozivnih materija veoma teško dobijaju. Nove lokacije, po pravilu, imaju daleko nepovoljniji položaj u odnosu na saobraćajnu i ostalu infrastrukturu, a za njihovo potpuno osposobljavanje potrebno je izdvojiti znatna materijalna sredstva. Ovi i ostali problemi često na- vode korisnike postojećih skladišta da ih koriste tako da u skladišne objekte smeštaju količine eksplozivnih materija veće od dozvoljenih sa aspekta minimalnih bezbednosnih rastojanja, čime se stvaraju mogućnosti da dođe do incidenata veoma velikih razmera.

Problemi koji se odnose na veličinu bezbednosnih rastojanja $\mathbf{i}$ iskorišćenje smeštajnih mogućnosti skladišnog objekta mogu biti dvojaki, u funkciji od prirode bezbednosnog rastojanja.

Bezbednosna rastojanja koja ne zavise od količine uskladištenog materijala, već samo od oblika dejstva eksplozivnih materija, onemogućavaju da se skladišni objekat koristi $u$ uslovima kada se nalazi na rastojanju manjem od minimalnog. Potpuno je jasno da se takav objekat, ukoliko je posmatrano bezbednosno rastojanje posledica potrebe za zaštitom objekta iz okruženja koji se ne može eliminisati, može koristiti samo za smeštanje materija koje ne spadaju u klasu eksplozivnih, ili onih eksplozivnih materija za koje je postojeće rastojanje dovoljno.

Međutim, ako je zabrana korišćenja objekta nastala kao posledica nedovoljnog rastojanja između dva skladišna objekta, stvara se mogućnost da se jedan od ova dva objekta i dalje koristi za smeštanje eksplozivnih materija iste klase, tako što bi jedan objekat bio eliminisan. Ovaj naizgled jednostavan problem, znatno se usložava činjenicom da skladišni kompleksi, po pravilu, imaju relativno veliki broj skladišnih objekata, pri čemu su svi objekti međusobno ugroženi.

U uslovima kada uskladištene opasne materije diktiraju postavljanje bezbednosnih rastojanja koja zavise od količine uskladištenih materija, potpuna zabrana korišćenja nekog od skladišnih objekata nije moguća. Problemi se tada odnose na određivanje količine materija koje mogu biti uskladištene, kao funkcije postojećeg rastojanja do 
objekta u okruženju ili do susednog skladišnog objekta, što je predstavljeno relacijom:

$$
\mathrm{q}=\mathrm{f}^{-1}\left(\mathrm{a}_{\mathrm{q}}, \mathrm{o}, \mathrm{s}\right)
$$

Ovako definisana količina materija, koja se može smestiti u jedan skladišni objekat, može usloviti veoma loše iskorišćenje njegove zapremine, pa je, kao i u prethodnom slučaju, moguće razmatrati eliminisanje jednog ili više objekata radi efikasnijeg korišćenja preostalih objekata.

Uočljivo je da se u oba slučaja, rešenje za optimalno korišćenje postojećih kompleksa za skladištenje eksplozivnih materija traži u eliminisanju nekih objekata, kako bi se preostali koristili na bolji način i kako bi se obezbedilo da se u kompleksu smesti ukupno više eksplozivnih materija.

Ovaj problem u znatnoj meri dobija na složenosti činjenicom da se $u$ kompleks smešta više klasa eksplozivnih materija koje zahtevaju različita bezbednosna rastojanja. Isto tako, u uslovima kada bezbednosna rastojanja zavise od količine uskladištenog materijala, postavlja se i problem dovođenja $u$ vezu zapremine objekta i količine u njemu smeštenog čistog eksploziva, s obzirom na primenjene tehnologije skladištenja i oblike pakovanja. Logično je da se o eliminaciji pojedinih objekata, kao putu koji vodi ka smeštanju većih količina materijala u 'skladišni kompleks, zbog izuzetne složenosti problema, može govoriti samo u uslovima homogenih, odnosno jednakih bezbednosnih rastojanja.

Posledica toga jeste da se eliminacija objekata može i mora obaviti za svaku od homogenih grupa rastojanja. Na ovaj način dolazi se do optimalne strukture objekata za svaku od homogenih grupa.

Više optimalnih struktura, sa jedne, i potreba da se u skladišni kompleks smesti širi asortiman eksplozivnih materija, sa druge strane, nameće potrebu da se precizno definiše namena svakog od objekata, odnosno, da se svaki od objekata poveže sa odgovarajućom grupom opasnih materija, homogenom sa aspekta veličine bezbednosnog rastojanja.

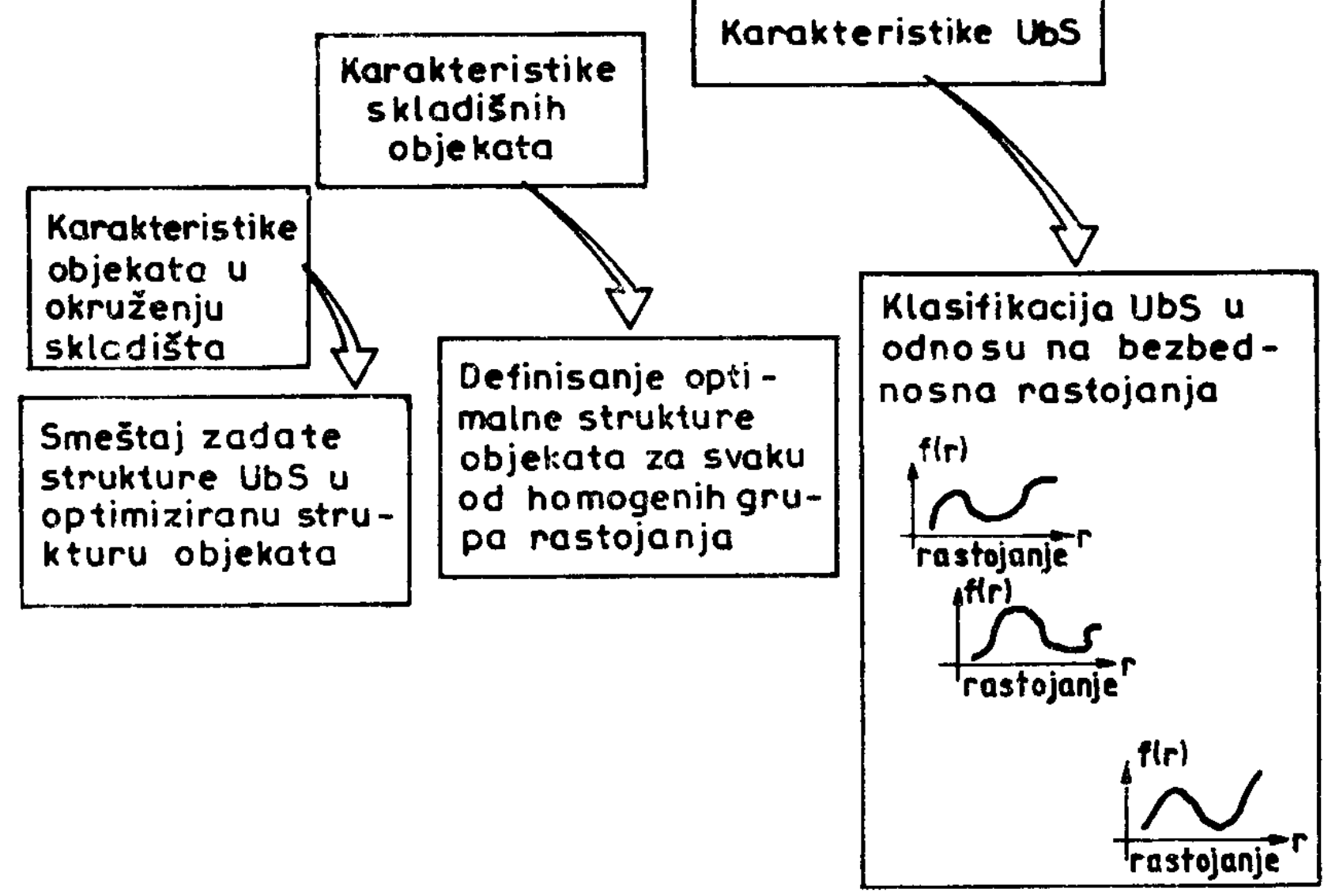

Sl. 1 - Osnovni koncept optimizacije postojećih skladišnih kompleksa 
Izloženi pristup problemu generiše dve osnovne grupe aktivnosti koje je neophodno primeniti kako bi osnovni cilj, definisan kao smeštanje maksimalnih količina eksplozivnih materija u postojeći kompleks, bio ostvaren. Ove grupe mogu se definisati kao: - definisanje optimalne strukture objekata u okviru jedne homogene grupe bezbednosnih rastojanja,

- postupak smeštaja zadate strukture UbS $\mathrm{u}$ optimiziranu strukturu objekata.

\section{Definisanje optimalne strukture objekata u okviru homogene grupe bezbednosnih rastojanja}

Definisanje optimalne strukture objekata, u okviru jedne homogene grupe bezbednosnih rastojanja, moguće je ostvariti primenjivanjem optimizacionih modela:

- SMD, u slučaju kada bezbednosna rastojanja ne zavise od količine eksplozivnih materija u skladišnom objektu,

- SME, ,kada bezbednosna rastojanja zavise od količine eksplozivnih materija u skladišnom objektu.

Bez obzira na vrstu eksplozivnih materija u kompleksu i na model koji će se primenjivati, neophodno je, $u$ prethodnom postupku, izvršiti analizu eksplozivnih materija kako bi se dobili realni parametri funkcionalne zavisnosti između bezbednosnih rastojanja i ostalih relevantnih faktora. Isto tako, neophodno je eliminisati sve skladišne objekte koji mogu ugroziti objekte u okruženju skladišnog kompleksa.

Definisanje optimalne strukture objekata u uslovima kada bezbednosna rastojanja ne zavise od količine eksplozivnih materija u skladišnom objektu

Optimizacija korišćenja postojećih kompleksa za skladištenje eksplozivnih materija, u uslovima postojanja bez- bednosnih rastojanja koja ne zavise od količine eksplozivnih materija $u$ skladišnom objektu, zasniva se na eliminaciji onih skladišta koja se ne mogu koristiti, jer su na manjem rastojanju od minimalnog. Zbog postojanja velikog broja mogućnosti za eliminaciju objekata, neophodno je uvesti kriterijum čijim bi se korišćenjem obezbedilo da novoformirana struktura objekata bude zaista optimalna. Kako je osnovni cilj optimizacije stvaranje mogućnosti da se u postojeće skladišne komplekse smesti maksimalna količina eksplozivnih materija, za kriterijum optimizacije treba odabrati neki od pokazatelja koji govori o iskorišćenosti skladišnih objekata. Pošto je kod nekih eksplozivnih materija, kao što je to slučaj sa onima iz klase 1.1 , od značaja ne samo ukupna količina izražena u jedinicama težine ili zapremine, već i specifična gustina pojedinih komponenti, logičan izbor kriterijuma je ukupna korisna zapremina svih skladišnih objekata u kompleksu.

Postupak optimizacije može biti zasnovan na definisanju pokazatelja korisnosti zadržavanja nekog od skladišnih objekata u strukturi, pri čemu bi se njegova vrednost dobila kao razlika između zapremine objekata koji su ostali u strukturi, zahvaljujući eliminaciji određenog broja objekata, i zapremine objekata koji su eliminisani iz strukture, prema relaciji:

$\mathrm{K}_{\mathrm{o}}=\sum_{\mathrm{i}=1}^{\mathrm{n}} \mathrm{V}_{\mathrm{i}}-\sum_{\mathrm{j}=1}^{\mathrm{m}} \mathrm{V}_{\mathrm{j}}$

gde je:

$V_{j}$ - zapremine objekata iz skupa onih koji se eliminišu iz strukture, jer je $a_{0 j}>a_{\min }$,

$\mathrm{V}_{\mathrm{i}}$ - zapremine objekata iz skupa onih koji ostaju u strukturi, kao posledica eliminacije objekata sa zapreminama $V_{j}$,

$K_{\mathrm{o}}$ - koeficijent korisnosti za objekat $\mathrm{O}$. 
Pokazatelj korisnosti utvrđuje se za svaki od skladišnih objekata koji u susedstvu ima objekat ili objekte na rastojanju manjem od minimalnog. Eliminisanjem tog ili tih objekata gubi se određena zapremina koja se pri proračunu pokazatelja korisnosti uvažava sa predznakom minus. Zahvaljujući eliminaciji, posmatrani i eventualno još neki objekti postaju upotrebljivi, jer njihova rastojanja do susednih objekata postaju veća od minimalnih. Zapremine ovih objekata se pri proračunu pokazatelja korisnosti uvažavaju sa predznakom plus.

Proračunom koeficijenta korisnosti za svaki objekat stvoreni su uslovi za objektivno identifikovanje objekta koji treba zadržati u strukturi, a samim tim i objekata koje treba eliminisati, a da se, pri tome, ostvare najveći korisni efekti. Jasno je da u strukturi treba zadržati onaj objekat za koji je utvrđeno da ima najveći koeficijent korisnosti, a eliminisati one objekte koji se od objekta sa najvećim koeficijentom korisnosti nalaze na rastojanju manjem od minimalnog.

Ceo ovaj postupak (proračun koeficijenata i eliminisanje objekata) ponavlja se dok se, postupkom eliminacije, ne obezbedi da svi skladišni objekti u kompleksu budu na rastojanju većem od minimalnog.

\section{Definisanje optimalne strukture objekata u uslovima kada bezbednosna rastojanja zavise od količine eksplozivnih materija u skladišnom objektu}

U slučajevima kada karakteristike eksplozivnih materija zahtevaju bezbednosna rastojanja koja zavise od uskladištene količine, potreba za eli-

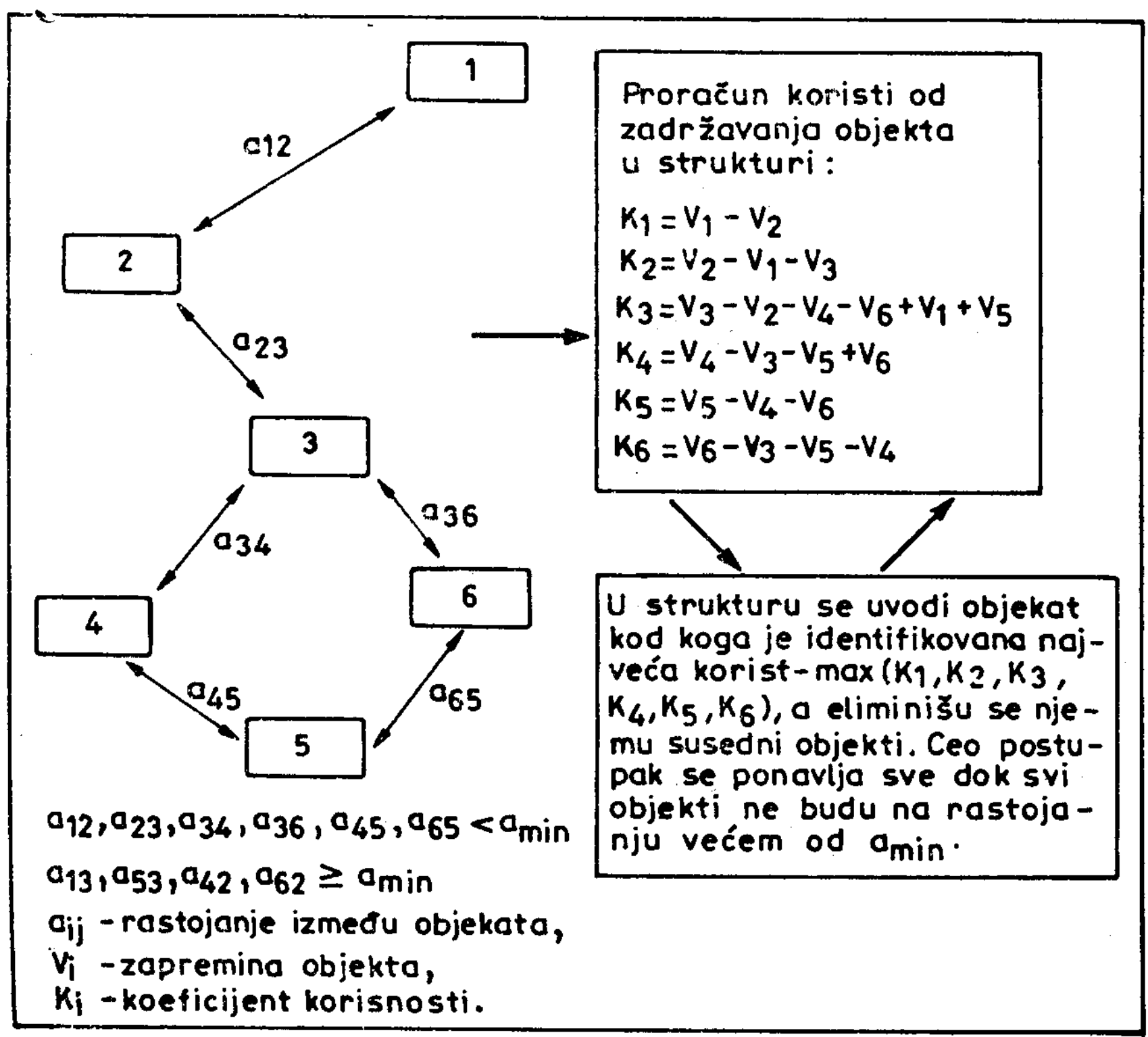

Sl. 2 - Primer primene modela SMD 
minacijom nekog od objekata, sa ciljem da se njemu susedni objekti osposobe za korišćenje, ne postoji. Teoretski posmatrano, bilo koje bezbednosno rastojanje, pa i ono najmanje, omogućava da se razmatrani objekat koristi. Naravno, u njega je moguće smestiti onoliko eksplozivnih materija koliko to postojeće bezbednosno rastojanje dozvoljava (izraz 3).

Međutim, i u ovom slučaju postoje mogućnosti za povećanjem ukupne količine eksplozivnih materija koje se mogu smestiti u skladišni kompleks. Slično prethodno opisanom postupku, i u ovom slučaju je moguće eliminisati jedan ili više objekata, kako bi se obezbedilo bolje korišćenje objekata koji ostaju u strukturi.

Bolje iskorišćenje zapremine proizvoljno izabranog objekta može se postići eliminacijom susednih objekata.
Logično je da se najmanji efekti postižu eliminacijom jednog, najbližeg, objekta. Najveće efekte moguće je ostvariti eliminacijom svih susednih objekata koji se nalaze na rastojanju manjem od onoga koje bi bilo potrebno ostvariti u slučaju da se zapremina posmatranog objekta iskoristi do maksimuma.

Slično kao u prethodnom slučaju, efekte eliminacije objekata moguće je egzaktno utvrditi proračunom koeficijenta korisnosti, u zavisnosti od eliminacije pojedinih objekata.

Koeficijent korisnosti mora se proračunati za svaki objekat koji ostaje u strukturi, i to posebno za sva$\mathrm{ku}$ od potencijalnih kombinacija eliminacije susednih objekata.

Proračunom koeficijenata korisnosti za svaki objekat stvoreni su uslovi da se, na objektivan način, odaberu ob-

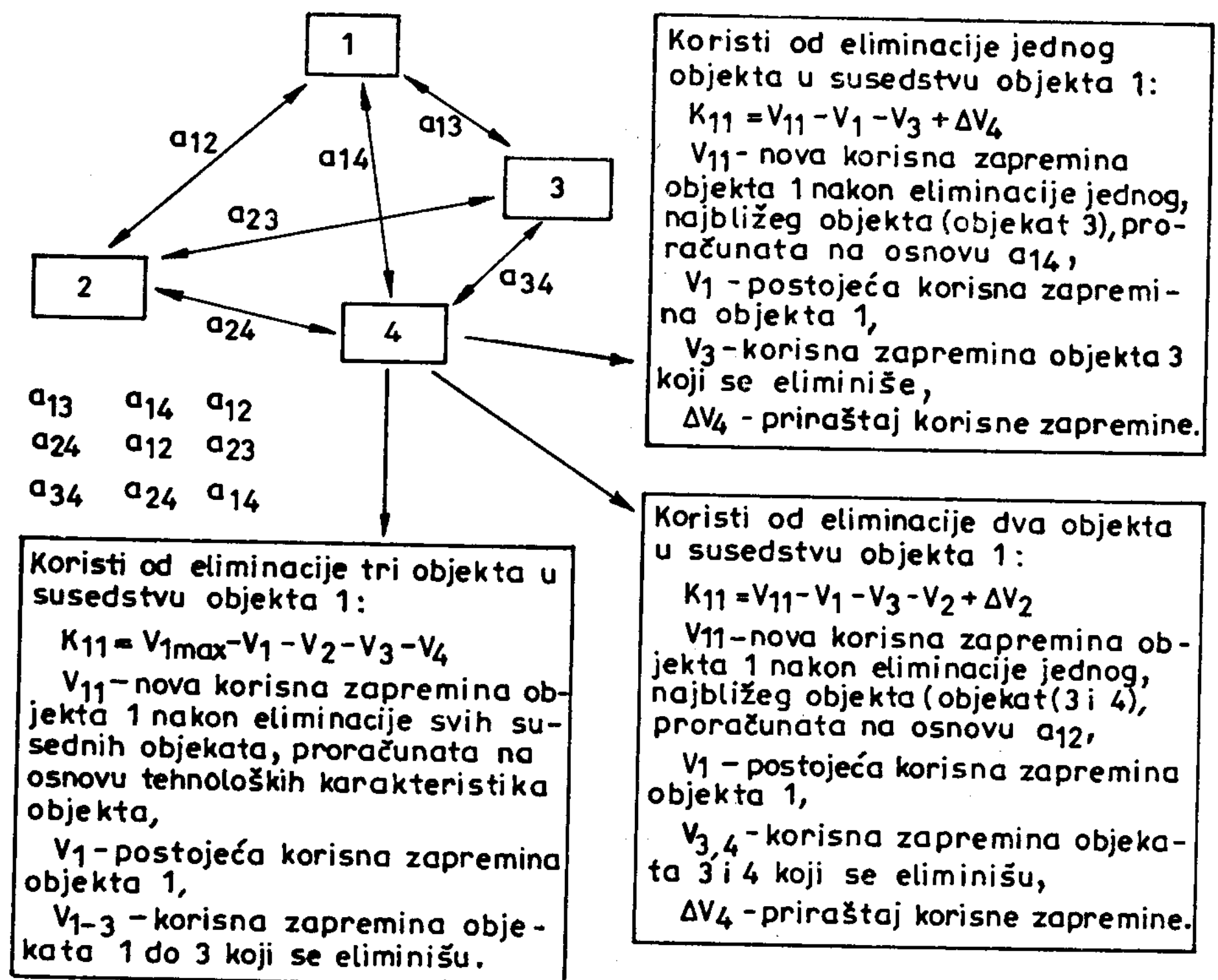

Sl. 3 - Proračun "korisnosti“ primenom modela SME 
jekti koje treba eliminisati, pa, prema tome, i objekat koji treba zadržati u strukturi.

Ceo opisani postupak treba ponavljati sve dotle dok se više ni za jedan objekat ne može definisati pozitivan koeficijent korisnosti, što ujedno znači da se novom eliminacijom bilo koje kombinacije objekata ne može ostvariti povećanje uskladištene količine eksplozivnih materija u skladišnom kompleksu.

Svaki od koeficijenata korisnosti povezuje se sa objektom za koji se ispituje opravdanost povećanja iskorišćenja njegove zapremine i kombinacijom objekata koje treba eliminisati kako bi ovo povećanje bilo ostvarljivo.

Kombinacije objekata za eliminaciju nastaju korišćenjem elemenata skupa objekata koje je moguće eliminisati.

Elementi ovog skupa Or dobijaju se kao podskup skupa svih skladišnih objekata u kompleksu za koje je ispunjen uslov:

$$
a_{r j}<f\left(V_{\text {rmax }}, o, s\right),
$$

gde je:

$a_{i j}$ - rastojanje od objekta $r$, za koji se ispituje opravdanost povećanja iskorišćenja zapremine, do objekta $j$,

$\mathrm{V}_{\text {rmax }}$ - zapremina objekta za koji se ispituje opravdanost povećanja iskorišćenja zapremine,

o - karakteristike eksplozivnih materija,

s - karakteristike skladišnog objekta,

$\mathrm{f}^{-1}$ - funkcionalna zavisnost između bezbednosnog rastojanja, zapremine objekta, karakteristika objekta i karakteristika eksplozivnih materija.

Elementi skupa Or uređeni su tako da rastojanja između objekta $r$ i objekata u posmatranom skupu formiraju rastući niz.
Nakon definisanja elemenata posmatranog skupa moguće je definisati i skup potencijalno ostvarljivih zapremina objekta $r, P V r$.

Element $l$, skupa $P V r$ koji odgovara elementu $l$ skupa $O r$, dobija se korišćenjem izraza:

$$
\mathrm{V}_{\mathrm{rl}}=\mathrm{F}^{-1}\left(\mathrm{a}_{\mathrm{rl}}, \mathrm{o}, \mathrm{s}\right)
$$

i predstavlja zapreminu koju je moguće iskoristiti u objektu $r$, uz uslov da se eliminiše $l$ objekata iz skupa $O r$.

Definisanjem elemenata ovih skupova stvorena je mogućnost za proračun koeficijenta korisnosti $u$ zavisnosti od povećanja iskorišćenja zapremine objekta $r$, uz eliminaciju $l$ objekata iz skupa $O r$, korišćenjem izraza:

$$
\mathrm{K}_{\mathrm{rl}}=\mathrm{V}_{\mathrm{rl}}-\mathrm{V}_{\mathrm{r}}-\sum_{\mathrm{i}=1}^{1} \mathrm{~V}_{\mathrm{l}}+\Delta \mathrm{V}
$$

gde je:

$\mathrm{K}_{\mathrm{rl}}$ - koeficijent korisnosti koji zavisi od povećanja iskorišćenja, zapremine objekta $r$ eliminisanjem $l$ objekta iz skupa $O r$,

$\mathrm{V}_{\mathrm{rl}}$ - zapremina koju je moguće ostvariti $\mathrm{u}$ objektu $r$ nakon eliminisanja $l$ objekata iz skupa Or,

$\mathrm{V}_{\mathrm{r}}$ - iskorišćena zapremina objekta $r$ pre eliminisanja objekata,

$\mathrm{V}_{\mathrm{j}}$ - zapremina eliminisanog objekta $j$,

$\Delta \mathrm{V}$ - priraštaj zapremine $\mathrm{u}$ ostalim objektima koji nastaje kao posledica eliminisanja $l$ objekata iz skupa $O p$.

Koristeći definisane izraze, koeficijente korisnosti moguće je proračunati za sve objekte u kompleksu. Izborom najvećeg koeficijenta korisnosti definiše se akcija koja podrazumeva eliminaciju određenog broja objekata i zadržavanje jednog od objekata, uz povećanje iskorišćenja njegove zapremine. Nakon eliminisanja jedne grupe objekata moguće je nanovo defi- 
nisati koeficijente korisnosti za novodobijenu strukturu objekata, čime se otvara mogućnost za novu eliminaciju objekata. Ovaj postupak se ponavlja sve dotle dok se ne utvrdi da nove eliminacije objekata ne mogu doprineti povećanju iskorišćenja zapremine objekata.

\section{Postupak smeštaja zadate strukture opasnih materija klase 1 u optimiziranu strukturu objekata}

Formiranje segmenata unutar kojih se smeštaju homogene grupe materija

Eliminacijom određenog broja objekata koji svojim položajem limitiraju smeštajne mogućnosti kompleksa, primenom prezentiranih optimizacionih modela (SMD i SME) utvrđuje se struktura objekata na rastojanjima koja maksimiziraju smeštajne karakte- ristike kompleksa. $\mathrm{S}$ obzirom na to da je primena izloženog postupka povezana sa brojem utvrđenih homogenih grupa bezbednosnih rastojanja među objektima, kao rezultat dobija se familija rešenja - jedna struktura objekata za svaku homogenu grupu minimalnih rastojanja među objektima.

Ako se dobijeni rezultati grafički predstave na situacionom planu kompleksa, tada je rezultat primene optimizacionih modela SMD i SME moguće šematski predstaviti kao na slici 4 .

Očigledno, s obzirom na razlike $u$ potrebnim minimalnim bezbednosnim rastojanjima, reč je i o različitim strukturama objekata, pri čemu je svaka "specijalizovana", sa aspekta mogućnosti smeštaja, samo za one materije koje zahtevaju isto rastojanje objekata. Međutim, pošto u realnim skladišnim kompleksima, posebno vojnim, postoji zahtev za smeštaj različitih materija i sredstava iz klase 1, bilo je neophodno definisati postupak koji će to omogućiti.

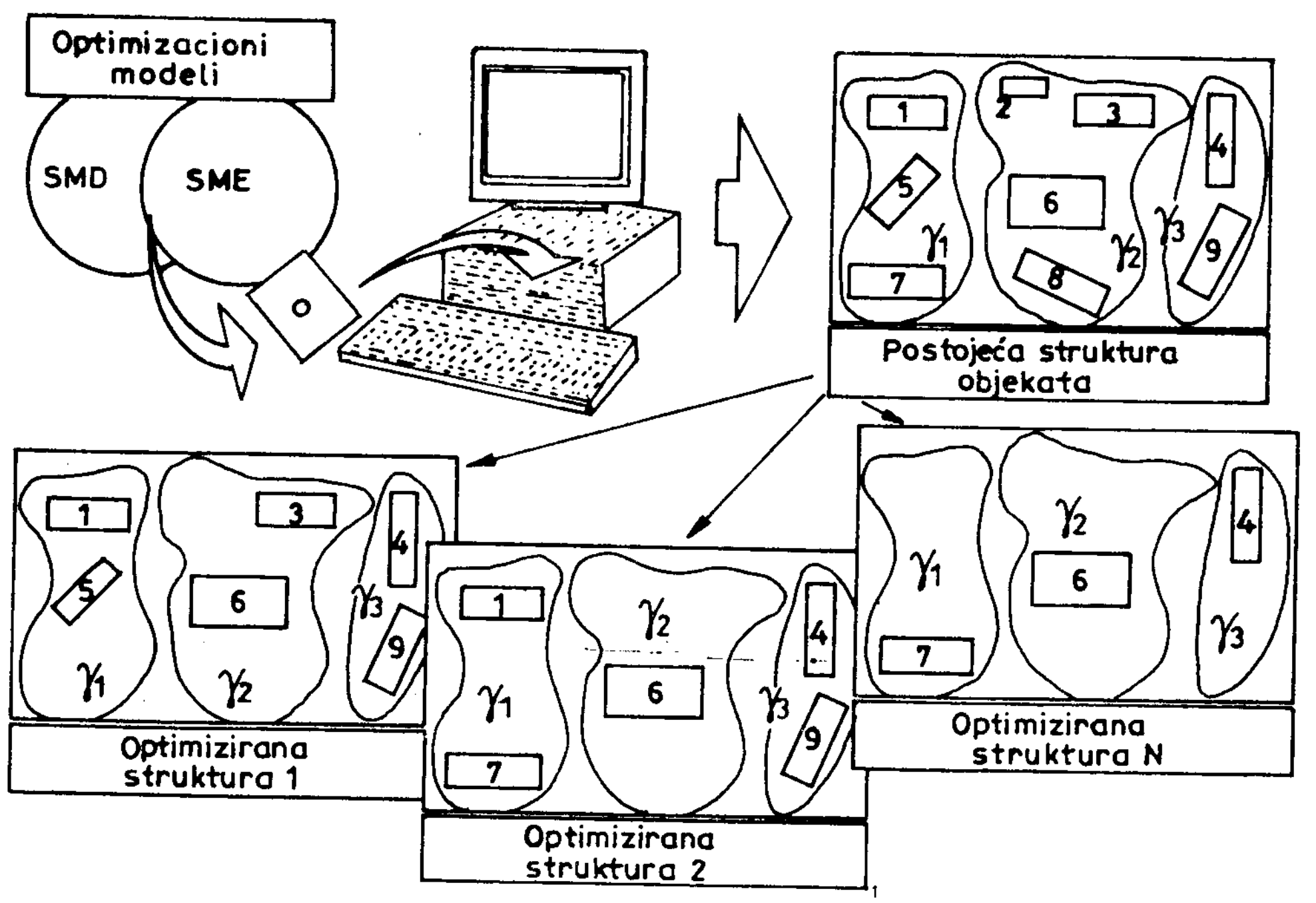

Sl. 4 - Grafički prikaz rezultata primene modela SMD i SME 
Rešavanje ovog problema na bazi kombinatornih procedura, zbog enormno velikog broja kombinacija moralo je biti odbačeno i u polaznom koraku postupka optimizacije, a zbog istog razloga nije primenjivo ni $\mathrm{u}$ okviru ove faze. Naime, veliki broj kombinacija i složeni i obimni proračuni koje je neophodno sprovesti za svaku od mogućih kombinacija, svrstavaju ovaj problem u klasu np-hard problema, što je bio osnovni razlog da se za praktičnu primenu razvije heuristička procedura.

$\mathrm{U}$ okviru te procedure $\mathrm{u}$ prvom koraku se vrši grupisanje objekata kao posledica podele kompleksa na određen broj segmenata. Na taj način obezbeđeno je da se grupa objekata unutar segmenta (slika 4) posmatra kao nezavisan entitet $\mathrm{u}$ koji se smešta jedna homogena grupa materija, pri čemu je, jednovremeno, kao posledica egzistencije većeg broja ovih segmenata u kompleksu, moguć smeštaj materija klase 1 iz različitih homogenih grupa. Segmenti unutar skladišnog kompleksa označeni sa $\gamma$, imaju fiksne prostorne granice i invarijantni su za različite strukture objekata. Invarijantnost ovih segmenata, tj. oblasti kompleksa, $s$ obzirom na razlike $u$ strukturi objekata za pojedina minimalna bezbednosna rastojanja, uslovila je i razlike $u$ broju, vrsti i rastojanju skladišnih objekata unutar oblasti $\gamma$. Tako, na primer, segment $\gamma_{1}$ koji $u$ postojećem stanju sadrži objekte 1,5 i 7, nakon optimizacije, za minimalna bezbednosna rastojanja $a_{\min 1}, a_{\min }$ i $a_{\operatorname{minN}}$ sadrži, respektivno, objekte 1,5, odnosno 1,7, odnosno 7 .

Formiranje segmenata $\gamma$ obavlja se u postupku logičke analize, uz respektovanje sledećih kriterijuma:

- rastojanje segmenata,

- rastojanje i dužina saobraćajnica unutar segmenata,

- veličina i broj objekata unutar segmenata, su,

- raspored objekata u komplek-

- zadata struktura i količina materija klase 1,

- pogodnost, segmentom obuhvaćene lokacije, za izgradnju novih objekata.

\section{Definisanje namene \\ pojedinih segmenata}

Problem utvrđivanja optimalne skladišne strukture - u ovom slučaju one koja omogućava smeštaj maksimalnih količina materije klase 1 , svodi se, praktično, na definisanje funkcije svakog od formiranih segmenata. Pri tome, svaki segment može imati jednu od $\mathrm{N}$ funkcija, odnosno, unutar segmenta moguće je smestiti jednu od $\mathrm{N}$ homogenih grupa materija klase 1 , pri čemu je smeštena količina funkcija vrste, broja i smeštajnih karakteristika objekata $u$ posmatranom segmentu.

Jasno je da kvantifikovanje količine koja se može smestiti u segment podrazumeva smeštaj svih homogenih grupa materija klase 1 u sve tipove objekata u kompleksu (slika 5).

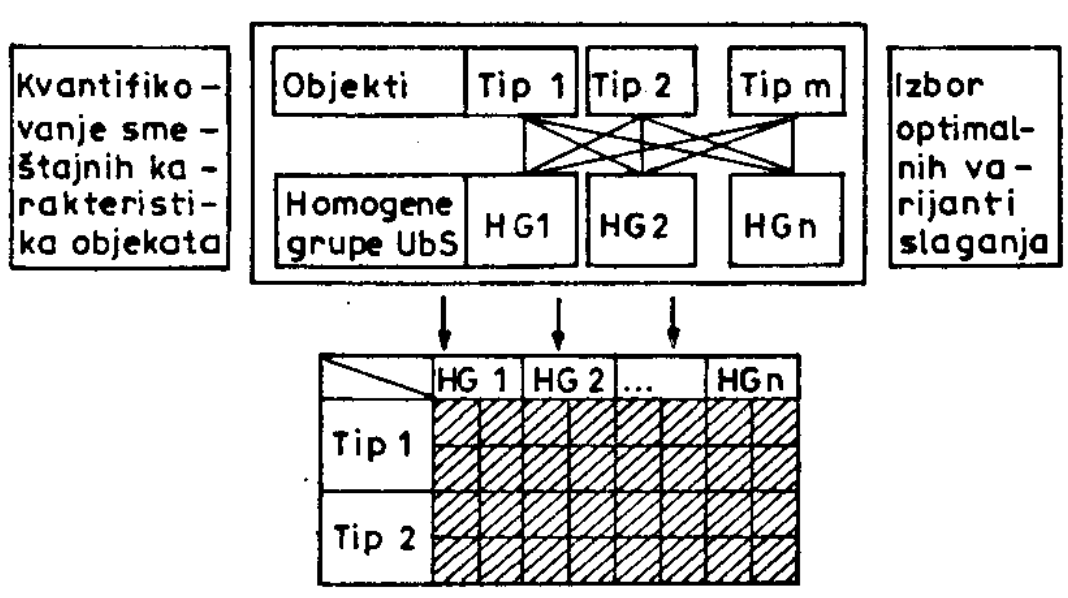

Sl. 5 - Analiza smeštajnih karakteristika objekata

Postupak utvrđivanja smeštajnih karakteristika objekata je, takođe, izuzetno složen, s obzirom na to da podrazumeva realizaciju čitavog niza aktivnosti. U okviru ovog koraka potre- 
bno je utvrditi karakteristike pojavnih oblika svih vrsta materija predviđenih za skladištenje u kompleksu, a za sve tipove objekata definišu se optimalne tehnologije slaganja. $\mathrm{Na}$ osnovu toga, i uz respekovanje svih propisa koji se odnose na oblast skladištenja, utvrđuju se maksimalne količine svake od homogenih grupa, koje je moguće smestiti u svaki tip objekta. Sabiranjem svih na opisani način utvrđenih količina, po svim objektima koji se za definisano minimalno bezbednosno rastojanje nalaze unutar određenog segmenta $\gamma$, određuje se i maksimalna količina materija klase I koja se može smestiti. Pri tome, treba imati u vidu da se, ukoliko je raspoloživa količina materija manja od smeštajnih mogućnosti segmenta, smeštena količina limitira raspoloživom.

Proces definisanja namene pojedinih segmenata realizuje se primenom heurističkog postupka zasnovanog na konceptu "koristi« koje se ostvaruju kao posledica smeštaja određene homogene grupe materija u segment.

Postupak definisanja namene pojedinih segmenata, uz primenu kriterijuma maksimalne ukupne smeštene količine, sadrži sledeće korake:

1. Formira se tabela sa brojem redova koji je jednak broju homogenih grupa materija i brojem kolona jednakim broju definisanih segmenata.

2. U polje $i-j$, koje se nalazi $u$ preseku i-te vrste $i \mathrm{j}$-te kolone, upisuje se količina materija i-te homogene grupe koja se može smestiti u j-ti segment. Ova količina se limitira raspoloživom količinom materija posmatrane grupe opasnosti.

3. Formira se polazno (bazično) rešenje u okviru kojeg se svakom segmentu $\gamma$ dodeljuje određena količina jedne od homogenih grupa.

4. Za svaki segment $\gamma$ proračunava se "korist" koja bi se ostvarila $u$ slučaju smeštaja one homogene grupe materija za koju je ukupna smeštena količina u segmentu maksimalna. („Korist « je ekvivalentna priraštaju ukupne količine smeštenih materija u kompleksu).

5. Poređenjem »koristi«, definisanih $\mathrm{u}$ prethodnom koraku, vrši se izbor najveće $i$ na itaj način definiše namena segmenta. (U segment se smešta ona materija koja je rezultovala najvećom »koristi«).

6. Količine materija u preostalim segmentima koriguju se u zavisnosti od raspoložive količine (raspoloživa količina se umanjuje za smeštenu) i postupak se ponavlja od koraka 4.

7. Kada sve »koristi« budu jednake nuli ili negativne, postupak je okončan, a dobijeno rešenje blizu optimalnom.

Nakon utvrđivanja funkcije pojedinih segmenata u skladišnom komple$\mathrm{ksu}$, pristupa se definisanju namene svakog objekta u segmentu.

\section{Definisanje namene skladišnih objekata unutar segmenta}

Svaki od segmenata sastoji se od objekata koji su preostali posle eliminacije, čiji je cilj bio omogućavanje smeštaja maksimalne količine materija iz određene homogene grupe, odnosno objekata koji se u kompleksu nalaze u postojećem stanju. Problem realnog smeštaja materija određene grupe opasnosti u izabrani segment $\gamma$ svodi se na ponovnu primenu izloženog heurističkog postupka, sada za pojedinačno popunjavanje neeliminisanih skladišnih objekata unutar segmenata. Treba naglasiti da objekti predviđeni za eliminaciju ne moraju fizički biti uklonjeni iz kompleksa, već se mogu koristiti za smeštaj materija koji ne pripadaju kategoriji opasnih. Pri tome, mora se imati $u$ vidu mogućnost da se pri pojavi akcidenta unište $\mathrm{i}$ ovi objekti.

Ukoliko ni nakon optimizacije strukture objekata u skladišni kom- 
pleks nije moguće smestiti zahtevanu količinu i strukturu opasnih materija klase 1, neophodno je, za preostalu količinu, pristupiti izgradnji novih objekata, bilo na istoj, ili na nekoj drugoj lokaciji.

\section{Zaključak}

Razvijen je model čijim se korišćenjem omogućava optimizacija postojećih kompleksa za skladištenje UbS, radi smeštanja maksimalnih količina ovih materija $u$ okviru postojeće strukture skladišnih objekata.

Primena modela podrazumeva postupke homogenizacije bezbednosnih rastojanja, eliminaciju objekata kako bi se obezbedilo smeštanje najvećih količina UbS i konkretno raspoređivanje zadatih količina UbS $u$ pojedine skladišne objekte.

Eliminacija objekata realizuje se u slučaju kada minimalna bezbednosna rastojanja, koja treba ostvariti između pojedinih objekata, ne zavise od količine eksplozivnih materija koje su smeštene u skladišne objekte $i$ kada ova zavisnost postoji. U oba slučaja, optimizacija se postiže eliminacijom pojedinih objekata, čime se postojeća rastojanja među objektima povećava-

\section{Literatura:}

[1] Transport of dangerous goods, OUN.

[2] Grupa autora: Tehnoloski projekat AX - 84, TU SSNO, Beograd, 1985. ju, a samim tim omogućava i smeštanje većih količina materija.

Eliminaciju treba shvatiti uslovno, kao zabranu da se neki od objekata koristi za skladištenje eksplozivnih materija, što ne isključuje mogućnost da se u njega smeste materije koje ne pripadaju klasi eksplozivnih.

Kao kriterijum za eliminaciju izabrana je ukupna korisna zapremina objekta, koja je posledica bezbednosnih rastojanja između objekata i primenjene tehnologije u skladišnom objektu.

U radu je prikazana osnovna koncepcija modela koji se može primeniti za većinu klasa eksplozivnih materija, a njihovo prilagođavanje za konkretne primene je relativno jednostavno. U većini slučajeva svodi se na precizno utvrđivanje zavisnosti između bezbednosnih rastojanja, vrste eksplozivnih materija, vrste objekata i odnosa zapremine objekta i parametara koji se koriste pri proračunu bezbednosnih rastojanja.

Ovi modeli mogu se nadograđivati korišćenjem ekonomskih parametara kao kriterijuma koji se koriste pri donošenju odluke o eliminaciji ili zadržavanju nekog objekta u strukturi skladišnog kompleksa.

[3] Grupa autora: Tehnološki projekat OB - 84, TU SSNO, Beograd, 1985. 